\title{
Genetic Variability, Heritability and Genetic Advance for Yield and its Contributing Traits in Garlic (Allium sativum L.)
}

\author{
Gaurav Singh ${ }^{1}$, C.N. Ram ${ }^{1}$, Angad Singh ${ }^{2}$, Shiv Prakash Shrivastav ${ }^{3}$, \\ Praveen Kumar Maurya ${ }^{1,}$ Prateek Kumar $^{1}$ and Sriom ${ }^{1}$
}

${ }^{1}$ Department of Vegetable Science, ${ }^{2}$ Department of Horticulture, ${ }^{3}$ Department of Genetics and Plant Breeding, Narendra Deva University of Agriculture and Technology, Narendra Nagar (Kumarganj), Faizabad-224 229 (U.P.), India

*Corresponding author

\section{A B S T R A C T}

\section{Keywords}

Garlic (Allium

sativum L.),

Genetic variability,

Heritability,

Genetic advance

and bulb yield

Article Info

Accepted:

15 January 2018

Available Online:

10 February 2018
The experiment on sixty genotypes including four check varieties (G-50, G-41, G-282 and Punjab Garlic) of garlic (Allium sativum L.) was conducted to work out the genetic variability, heritability and genetic advance effects of their various attributes on yield per plant. The maximum bulb yield per plant was observed in NDG-26 (29.97 g) followed by NDG-41 (29.30 g) and NDG-5 (28.22 g) against the general mean $23.40 \mathrm{~g}$. While the minimum bulb yield per plant was recorded in NDG-31 $(15.13 \mathrm{~g})$. The high estimates of genotypic and phenotypic coefficient of variation were recorded as 28.74 and 28.77 per cent, respectively for width of leaf. The high magnitude of genotypic and phenotypic coefficients of variation were observed for width of leaf, length of clove, diameter of clove, indicating thereby, substantial scope for improvement in this character after hybridization and subsequent selection and the high estimate of heritability with high genetic advance in per cent of mean were observed for width of leaf, width of clove, neck thickness of bulb, diameter of clove. Heritability and genetic advance indicate that the additive nature of gene action and reliability of those characters for selection and emerged as ideal traits for improvement through selection.

\section{Introduction}

Garlic (Allium sativum L.) is classified under the class monocotyledone $2 \mathrm{n}=2 \mathrm{x}=16$, and belongs to the section Porrum of the family Alliaceae. It is known as Lahsun in Hindi, is the second important bulb crop after onion grown in India. It is also important foreign exchange earner and used as spices and condiments. Garlic is rich in protein, phosphorus, potassium, calcium and carbohydrates and also considered as "Nectar of Life" in Ayurveda. A compound bulb contains the edible product of this crop. Garlic is used all over the world for flavouring, different kinds of food materials and as condiments, notable in chutneys, pickles, curry powders, curried vegetables, meat preparation, tomato ketchup in medieval Europe, it is widely used for distinguishing the smell and flavour of salted meat, fish in the Philippines, much of Eastern Asia and 
other parts of tropics. Garlic is cultivated from long ancient times. Its wild ancestor Allium longicuspis Regel is native to Central Asia. It is well known in pre-dynastic cemeteries in Egypt before 3,000 B.C. It was reached to China and India and grown widely since a long times and carried out to Western hemisphere by Spanish, Portuguese and French and widely grown and used in Mediterranean climates. The major garlic growing countries are France, Spain, U.S.A. Brazil and Egypt. Asia contributes major parts in total world production. It was used in England as early as first half of the $16^{\text {th }}$ Century. It is frost resistant vegetable crop grown throughout the India. China is the leading country in area and production of garlic followed by India. In India, the total area covered under garlic is about 0.26 Million hectare with production of 1.42 Million tonnes and their productivity is 5.43 tonnes per hectare of bulb (Anonymous, 2015). Madhya Pradesh is the leading state in garlic production, its share, 0.06 Million hectare area with 0.27 Million tonnes production. The important garlic growing states are Gujarat, Maharashtra, Uttar Pradesh, Andhra Pradesh, Orissa, Tamil Nadu and Rajasthan. The alliin of Allium sativum contains an allyl radical from which the pungent Diallyl di-sulphide, is derived, which is responsible for pungency in garlic. Garlic contains $0.1-0.4 \%$ essential oil. The chief constituents of the oil are diallyldi-sulphide (60\%), diallyltrisulphide (20\%), allyl-propyl disulphide $(6 \%)$ and small quantity of diethyl disulphide. Garlic has good medicinal properties. It is carminative, gastric stimulants, helps in the digestion of food $\&$ absorption of nutrient from it. The inhalation of garlic oil or garlic juice has generally been recommended in case of pulmonary tuberculosis, rheumatism, sterility, impotency, cough and red eyes. Augusti (1977), reported that allicin, which has a hypo-cholesterolemic action, is present in aqueous extract of garlic and reduces the cholesterol concentration in human blood which is responsible for heart attack. Garlic juice is also used as medicine in various skin diseases.

The information usually needed for developing high yielding varieties in a particular species pertains to the extent of genetic variability for desirable traits in the available germplasm. Evaluation of germplasm is the basic tool for identification of important genotypes. The great extent of natural variation present in various characters among the genotypes suggests good scope of improvement in economic traits. Large variability ensures better chance of producing new forms. Variability parameters like genotypic and phenotypic coefficient of variation, heritability and genetic advance, besides degree of association between the various characters and direct effect of yield contributing characters on total yield, is of paramount significance in formulating an appropriate breeding strategy aimed at exploiting the inherent variability of the original population.

Phenotypic variability changes under different environmental conditions while genetic variability remains unchanged and more useful to a plant breeder for exploitation in selection or hybridization. Yield is very complex characteristics controlled by several yield contributing components and it is highly influenced by environmental factors, consequently estimates of heritability and genetic advance are useful for selection. Estimation of correlation co-efficient among the yield contributing characters is necessary to understand the direction of selection and maximize yield. Path coefficient provides an effective means of entangling direct and indirect causes of association of selection and measures the relative importance of each causal factor. 


\section{Materials and Methods}

The study was designed to work out the status of genetic variability, heritability and genetic advance effects of their various attributes on yield per plant among 60 garlic genotypes at field experiment under present investigation was conducted during Rabi 2014-15 at the Main Experiment Station, Vegetable Science, N. D. University of Agriculture and Technology, Narendra Nagar (Kumarganj), Faizabad (U.P.) India. The experimental materials of studies comprised of 60 garlic genotypes including four check varieties viz., G-50, G-41, G-282 and Punjab Garlic. The experiment was laid out in Augmented Block Design, with plot size of $2.0 \times 0.60 \mathrm{~m}^{2}$ with distance of $30 \mathrm{~cm}$ row to row and $10 \mathrm{~cm}$ plant to plant. Observation were recorded on plant height $(\mathrm{cm})$, number of leaves per plant, length of leaf $(\mathrm{cm})$, width of leaf $(\mathrm{cm})$, neck thickness of bulb $(\mathrm{cm})$, diameter of bulb $(\mathrm{cm})$, length of bulb $(\mathrm{cm})$, bulb yield per plant $(\mathrm{g})$, number of cloves per bulb, length of clove $(\mathrm{cm})$, weight of clove $(\mathrm{g})$, diameter of clove (cm) and total soluble solids (\%).The analysis of variance for different characters in "Augmented Design" was done according to Federer (1956). Variability for different characters was estimated as suggested by Burton and de Vane (1953). Expected genetic advance $(\overline{\mathrm{Ga}})$ was estimated by the method suggested by Johnson et al., (1955).

\section{Results and Discussion}

The result of analysis of variance for Augmented Design was carried out for thirteen characters and the results obtained are presented in table 1 .

The variation due to the blocks were highly significant for all the characters and variance due to checks were also highly significant for all the characters like plant height (112.62 $\mathrm{cm})$, number of leaves per plant (0.45), length of leaf $(46.70 \mathrm{~cm})$, width of leaf $(1.02 \mathrm{~cm})$, diameter of bulb $(0.39 \mathrm{~cm})$, length of bulb $(2.47 \mathrm{~cm})$, neck thickness of bulb $(0.07 \mathrm{~cm})$, number of cloves per bulb (82.46), bulb yield per plant $(35.91 \mathrm{~g})$, length of clove $(1.81 \mathrm{~cm})$, weight of clove $(0.25 \mathrm{~g})$, diameter of clove $(0.21 \mathrm{~cm})$ and TSS $(9.26 \%)$. Similar results were reported by Agrawal and Tiwari (2004), Khar et al., (2005).

Sixty genotypes of garlic including four checks namely G-50, G-41, G-282 and Punjab Garlic were evaluated for various traits and there mean performance is described here under table 2.

The data pertaining to this trait revealed that maximum plant height was observed in NDG$19(72.50 \mathrm{~cm})$. The minimum plant height was observed in NDG-11 $(49.70 \mathrm{~cm})$ against the general mean of $(60.64 \mathrm{~cm})$. Thirty genotypes namely NDG-2, NDG-3, NDG-4, NDG-12, NDG-19, NDG-20, NDG-21, NDG22, NDG-25, NDG-26, NDG-27, NDG-28, NDG-29, NDG-35, NDG-38, NDG-41, NDG42, NDG-43, NDG-44, NDG-45, NDG-46, NDG-47, NDG-48, NDG-49, NDG-50, NDG51, NDG-54, NDG-56, G-50 and Punjab Garlic, were exhibited higher mean values as compared to general mean (60.64), while NDG-1, NDG-5, NDG-6, NDG-7, NDG-8, NDG-9, NDG-10, NDG-11, NDG-13, NDG14, NDG-15, NDG-16, NDG-17, NDG-18, NDG-23, NDG-24, NDG-30, NDG-31, NDG32, NDG-33, NDG-34, NDG-36, NDG-37, NDG-39, NDG-40, NDG-52, NDG-53, NDG55, G-41 and G-282, showed lower mean values. The genotypes exhibited considerable variation for the number of leaves per plant. It ranged from 6.75 to 10.47 , the maximum leaves per plant was recorded in NDG-52 (10.47) followed by NDG-54 (10.37) and NDG-51 (10.27), while the minimum leaves in NDG-36 (6.75) against the general mean of (8.23). Length of leaf exhibited sufficient variability ranged from $29.86 \mathrm{~cm}$ to $45.57 \mathrm{~cm}$. 
The maximum length of leaf was recorded in NDG-45 $(45.57 \mathrm{~cm})$ followed by NDG-46 $(45.17 \mathrm{~cm})$ and NDG-50 $(44.62 \mathrm{~cm})$, while the minimum leaf length in NDG-16 (29.86 $\mathrm{cm})$ against the general mean of $(36.31 \mathrm{~cm})$. The maximum width of leaf was recorded in NDG-52 $(3.43 \mathrm{~cm})$ followed by NDG-53 $(3.26 \mathrm{~cm})$, while minimum in NDG-45 $(0.98$ $\mathrm{cm})$ against the general mean $(1.36 \mathrm{~cm})$. The diameter of bulb ranged from $2.72 \mathrm{~cm}$ to 4.73 $\mathrm{cm}$ against the general mean of $3.60 \mathrm{~cm}$. The maximum diameter of bulb was recorded in NDG-50 $(4.73 \mathrm{~cm})$ followed by NDG-4 (4.70 $\mathrm{cm})$, NDG-17 (4.56 cm), NDG-3 (4.38 cm), NDG-27 $(4.35 \mathrm{~cm})$ and NDG-11 $(4.32 \mathrm{~cm})$. The minimum diameter of bulb was observed in NDG-32 $(2.72 \mathrm{~cm})$. The maximum length of bulb was recorded in NDG-21 $(6.06 \mathrm{~cm})$ followed by NDG-55 (5.89 cm), NDG-27 $(5.88 \mathrm{~cm})$ and NDG-51 $(5.85 \mathrm{~cm})$, while the minimum length was observed in NDG-31 $(3.41 \mathrm{~cm})$ against the general mean of $(5.14$ $\mathrm{cm})$. The maximum neck thickness of bulb was recorded in NDG-3 $(2.06 \mathrm{~cm})$. The mean value of neck thickness of bulb ranged from $1.00 \mathrm{~cm}$ to $2.06 \mathrm{~cm}$ against the general mean of $1.55 \mathrm{~cm}$. The minimum neck thickness of bulb was recorded in NDG-33 $(1.00 \mathrm{~cm})$. The maximum bulb yield per plant was observed in NDG-26 (29.97 g) followed by NDG-41 (29.30 g) and NDG-5 (28.22 g) against the general mean $23.40 \mathrm{~g}$. While the minimum bulb yield per plant was recorded in NDG-31 $(15.13 \mathrm{~g})$. The minimum and maximum value for number of cloves per bulb ranged from 10.46 to 28.16 against the general mean of 20.56. The maximum number of cloves per bulb was recorded in NDG-42 (28.16) followed by NDG-9 (27.77), NDG-22 (26.73) and NDG-2 (26.70). While minimum cloves per bulb was recorded in NDG-54 (10.46). The maximum length of clove was recorded in NDG-52 $(3.83 \mathrm{~cm})$ followed by NDG-43 $(3.78 \mathrm{~cm}), \mathrm{NDG}-30(3.69 \mathrm{~cm}), \mathrm{NDG}-54(3.63$ $\mathrm{cm})$ and NDG-23 $(3.57 \mathrm{~cm})$ against the general mean of $2.68 \mathrm{~cm}$, while the minimum length of clove was recorded in NDG-17 $(1.15 \mathrm{~cm})$. The minimum and maximum value of weight of clove ranged from $1.00 \mathrm{~g}$ to 2.08 $\mathrm{g}$ against the general mean of $1.18 \mathrm{~g}$. The highest weight of clove was recorded in NDG-26 (2.08 g) followed by NDG-39 (2.03 g), NDG-41 (1.89 g), NDG-33 (1.62 g) and NDG-11 $(1.57 \mathrm{~g})$, while the lowest weight of clove was recorded in NDG-9 (1.00 g). The mean value of diameter of clove ranged from $0.86 \mathrm{~cm}$ to $2.01 \mathrm{~cm}$ against the general mean $1.48 \mathrm{~cm}$. The maximum diameter of clove was recorded in NDG-28 $(2.01 \mathrm{~cm})$ followed by NDG-12 $(1.99 \mathrm{~cm})$, NDG-47 $(1.96 \mathrm{~cm})$ and NDG-15 $(1.91 \mathrm{~cm})$, while the minimum diameter of clove was observed in NDG-54 $(0.86 \mathrm{~cm})$. The large amount of variability was found for total soluble solids (TSS \%) per cent. The mean value of TSS ranged from 28.64 to 41.04 per cent. The maximum TSS was recorded in NDG-26 (41.04\%) followed by NDG-52 (40.99\%), NDG-18 (40.90\%), NDG-55 (40.80\%) and NDG-37 (40.63\%). The minimum TSS was recorded in NDG-36 $(28.64 \%)$.

The data of genetic parameters for different traits are given in table-3. The results derived from this table are given below character wise. The estimates of genotypic and phenotypic coefficient of variation were 6.99 $\%$ and $7.30 \%$, respectively and the estimate of heritability was higher $91.64 \%$ and low genetic advance in per cent of mean (13.78 $\%)$ for Plant height. The estimates of genotypic and phenotypic coefficient of variation were recorded as $8.71 \%$ and 8.88 $\%$, respectively and the estimate of heritability in broad sense was high $(96.18 \%)$ with low genetic advance in per cent of mean i.e. 17.60 for number of leaves per plant. The estimates of genotypic and phenotypic coefficient of variation were recorded as 9.11 and 9.26 per cent, respectively and the estimate of heritability in broad sense was high $(96.86 \%)$ with low genetic advance in 
per cent of mean i.e. 18.48 for length of leaf. The estimates of genotypic and phenotypic coefficient of variation were recorded as 28.74 and 28.77 per cent, respectively and the estimate of heritability in broad sense was high $(99.78 \%)$ with higher genetic advance in per cent of mean i.e. 59.14 for width of leaf. The estimates of genotypic and phenotypic coefficient of variation were recorded as 10.63 and 10.76 per cent, respectively for diameter of bulb. The estimate of heritability in broad sense was high (97.70\%) with moderate genetic advance in per cent of mean i.e. 21.66 for diameter of bulb. The estimates of genotypic and phenotypic coefficient of variation were recorded as 8.60 and 8.76 per cent, respectively and the estimate of heritability in broad sense was high $(96.50 \%)$ with low genetic advance in per cent of mean i.e. 17.41 for length of bulb. The estimates of genotypic and phenotypic coefficient of variation were recorded as 14.75 and 14.80 per cent, respectively and the estimate of heritability in broad sense was high $(99.36 \%)$ with higher genetic advance in per cent of mean i.e. 30.30 for neck thickness of bulb.

Table.1 Analysis of variance (Augmented design) for thirteen characters in garlic germplasm

\begin{tabular}{|c|c|c|c|}
\hline \multirow[t]{3}{*}{ Characters } & \multicolumn{3}{|c|}{ Sources of variation } \\
\hline & Blocks & Check & Error \\
\hline & 7 (d.f) & 3 (d.f) & 21 \\
\hline Plant height $(\mathrm{cm})$ & $17.24 * *$ & $112.62 * *$ & 1.64 \\
\hline $\begin{array}{l}\text { Number of leaves per } \\
\text { plant }\end{array}$ & $1.78 * *$ & $0.45 * *$ & 0.02 \\
\hline Length of leaf $(\mathrm{cm})$ & $27.83 * *$ & $46.70 * *$ & 0.35 \\
\hline Width of leaf $(\mathrm{cm})$ & $0.21 * *$ & $1.02 * *$ & 0.00 \\
\hline Diameter of Bulb $(\mathrm{cm})$ & $0.16^{* *}$ & $0.39 * *$ & 0.00 \\
\hline Length of Bulb $(\mathrm{cm})$ & $0.58 * *$ & $2.47 * *$ & 0.00 \\
\hline $\begin{array}{l}\text { Neck Thickness of } \\
\text { Bulb }(\mathrm{cm})\end{array}$ & $0.06 * *$ & $0.07 * *$ & 0.00 \\
\hline $\begin{array}{l}\text { Bulb Yield per plant } \\
(\mathrm{g})\end{array}$ & $7.04 * *$ & $35.91 * *$ & 0.19 \\
\hline $\begin{array}{l}\text { Number of cloves per } \\
\text { Bulb }\end{array}$ & $10.07 * *$ & $82.46 * *$ & 0.14 \\
\hline Length of Clove $(\mathrm{cm})$ & $0.70 * *$ & $1.81 * *$ & 0.00 \\
\hline Weight of Clove (g) & $0.03 * *$ & $0.25 * *$ & 0.00 \\
\hline $\begin{array}{l}\text { Diameter of Clove } \\
(\mathrm{cm})\end{array}$ & $0.11 * *$ & $0.21 * *$ & 0.00 \\
\hline $\begin{array}{l}\text { Total Soluble Solids } \\
(\%)\end{array}$ & $5.99 * *$ & $9.26 * *$ & 0.57 \\
\hline
\end{tabular}

*,** Significant at $5 \%$ and $1 \%$ probability level, respectively 
Table.2 Mean performance of 60 genotypes for 13 characters in garlic

\begin{tabular}{|c|c|c|c|c|c|c|c|c|c|c|c|c|c|c|}
\hline $\begin{array}{c}\text { S. } \\
\text { No. }\end{array}$ & $\begin{array}{l}\text { Characters } \\
\text { No. of } \\
\text { Genotypes }\end{array}$ & $\begin{array}{c}\text { Plant } \\
\text { height } \\
(\mathrm{cm})\end{array}$ & $\begin{array}{c}\text { Number } \\
\text { of } \\
\text { leaves } \\
\text { per } \\
\text { plant }\end{array}$ & $\begin{array}{c}\text { Length } \\
\text { of leaf } \\
\text { (cm) }\end{array}$ & $\begin{array}{c}\text { Width } \\
\text { of leaf } \\
(\mathrm{cm})\end{array}$ & $\begin{array}{c}\text { Diameter } \\
\text { of bulb } \\
\text { (cm) }\end{array}$ & $\begin{array}{l}\text { Lengt } \\
\text { h of } \\
\text { bulb } \\
(\mathrm{cm})\end{array}$ & $\begin{array}{c}\text { Neck } \\
\text { Thickne } \\
\text { SS of } \\
\text { bulb } \\
\text { (cm) }\end{array}$ & $\begin{array}{c}\text { Bulb } \\
\text { Yield } \\
\text { per } \\
\text { plant } \\
\text { (g) }\end{array}$ & $\begin{array}{c}\text { Numb } \\
\text { er of } \\
\text { Cloves } \\
\text { per } \\
\text { bulb }\end{array}$ & $\begin{array}{l}\text { Lengt } \\
\text { h of } \\
\text { Clove } \\
(\mathrm{cm})\end{array}$ & $\begin{array}{l}\text { Weight } \\
\text { of } \\
\text { Clove } \\
\text { (g) }\end{array}$ & $\begin{array}{c}\text { Diamet } \\
\text { er of } \\
\text { Clove } \\
\text { (cm) }\end{array}$ & $\begin{array}{c}\text { T.S.S. } \\
(\%)\end{array}$ \\
\hline 1 & NDG-1 & 57.44 & 8.23 & 34.32 & 1.08 & 3.14 & 5.74 & 1.26 & 25.22 & 20.70 & 2.48 & 1.21 & 1.31 & 35.95 \\
\hline 2 & NDG-2 & 62.24 & 9.03 & 32.48 & 1.09 & 3.20 & 5.58 & 1.32 & 27.62 & 26.70 & 2.60 & 1.02 & 1.70 & 39.33 \\
\hline 3 & NDG-3 & 62.24 & 7.63 & 33.82 & 1.12 & 4.38 & 5.31 & 2.06 & 21.62 & 19.90 & 2.96 & 1.04 & 0.93 & 38.98 \\
\hline 4 & NDG-4 & 61.24 & 8.23 & 30.32 & 1.05 & 4.70 & 4.26 & 1.64 & 21.02 & 19.50 & 3.24 & 1.07 & 1.41 & 39.58 \\
\hline 5 & NDG-5 & 56.84 & 7.83 & 32.27 & 1.15 & 4.10 & 4.52 & 1.81 & 28.22 & 24.90 & 2.04 & 1.12 & 1.70 & 38.99 \\
\hline 6 & NDG-6 & 55.84 & 7.93 & 30.44 & 1.18 & 3.20 & 4.92 & 1.82 & 25.52 & 23.20 & 2.26 & 1.09 & 1.57 & 37.75 \\
\hline 7 & NDG-7 & 55.44 & 8.23 & 35.54 & 1.98 & 4.13 & 5.06 & 1.38 & 21.72 & 19.30 & 1.88 & 1.09 & 1.40 & 37.95 \\
\hline 8 & NDG-8 & 57.11 & 8.03 & 35.47 & 1.07 & 3.92 & 4.80 & 1.70 & 26.07 & 24.97 & 1.49 & 1.03 & 1.77 & 36.74 \\
\hline 9 & NDG-9 & 57.70 & 8.23 & 38.66 & 1.15 & 3.64 & 4.90 & 1.71 & 27.87 & 27.77 & 2.61 & 1.00 & 1.67 & 34.30 \\
\hline 10 & NDG-10 & 59.20 & 8.43 & 38.56 & 1.14 & 3.71 & 5.40 & 1.65 & 22.56 & 22.57 & 2.53 & 1.68 & 1.43 & 32.02 \\
\hline 11 & NDG-11 & 49.70 & 8.83 & 31.33 & 1.23 & 4.32 & 4.64 & 1.55 & 19.87 & 12.77 & 3.39 & 1.57 & 1.52 & 39.40 \\
\hline 12 & NDG-12 & 60.70 & 9.23 & 36.81 & 1.01 & 3.72 & 4.80 & 1.53 & 22.88 & 19.97 & 2.71 & 1.12 & 1.99 & 39.22 \\
\hline 13 & NDG-13 & 58.70 & 8.83 & 31.37 & 1.85 & 3.32 & 4.44 & 1.73 & 19.87 & 18.17 & 3.21 & 1.10 & 1.47 & 32.94 \\
\hline 14 & NDG-14 & 58.30 & 7.83 & 31.27 & 1.43 & 3.12 & 5.20 & 1.71 & 26.07 & 25.77 & 2.57 & 1.13 & 1.67 & 38.72 \\
\hline 15 & NDG-15 & 58.30 & 8.22 & 32.75 & 1.21 & 3.17 & 5.54 & 1.83 & 21.70 & 16.36 & 2.50 & 1.31 & 1.91 & 37.86 \\
\hline 16 & NDG-16 & 59.50 & 7.82 & 29.86 & 1.11 & 3.93 & 5.16 & 1.47 & 22.72 & 20.96 & 2.08 & 1.05 & 1.47 & 39.40 \\
\hline 17 & NDG-17 & 57.30 & 7.72 & 35.80 & 1.98 & 4.56 & 5.13 & 1.23 & 20.90 & 20.16 & 1.15 & 1.01 & 1.01 & 34.15 \\
\hline 18 & NDG-18 & 52.70 & 7.62 & 35.28 & 1.38 & 3.59 & 4.83 & 1.92 & 27.01 & 21.56 & 2.34 & 1.20 & 1.71 & 40.90 \\
\hline 19 & NDG-19 & 72.50 & 8.22 & 31.45 & 1.27 & 3.13 & 5.03 & 1.65 & 26.20 & 21.57 & 1.50 & 1.18 & 1.04 & 39.90 \\
\hline
\end{tabular}




\begin{tabular}{|c|c|c|c|c|c|c|c|c|c|c|c|c|c|c|}
\hline 20 & NDG-20 & 67.9 & 8.32 & 36.00 & 1.28 & 3.46 & 5.63 & 1.79 & 23.90 & 21.96 & 2.28 & 1.07 & 1.17 & 38.30 \\
\hline 21 & NDG-21 & 65.50 & 8.22 & 33.72 & 1.24 & 3.06 & 6.06 & 1.62 & 23.12 & 21.76 & 2.88 & 1.03 & 1.21 & 36.76 \\
\hline 22 & NDG-22 & 66.01 & 7.33 & 34.21 & 1.25 & 3.75 & 5.78 & 1.36 & 27.07 & 26.73 & 2.87 & 1.01 & 0.97 & 38.24 \\
\hline 23 & NDG-23 & 58.91 & 7.13 & 31.72 & 1.26 & 4.15 & 5.18 & 1.24 & 18.18 & 14.53 & 3.57 & 1.21 & 1.84 & 35.84 \\
\hline 24 & NDG-24 & 55.71 & 7.33 & 31.54 & 1.60 & 4.00 & 5.51 & 1.39 & 27.27 & 19.13 & 3.23 & 1.42 & 1.36 & 37.28 \\
\hline 25 & NDG-25 & 62.11 & 7.03 & 38.84 & 1.15 & 3.70 & 5.09 & 1.92 & 22.06 & 22.13 & 3.69 & 1.04 & 1.03 & 38.31 \\
\hline 26 & NDG-26 & 71.91 & 7.93 & 38.86 & 1.54 & 3.85 & 5.69 & 1.99 & 29.97 & 14.53 & 3.43 & 2.08 & 1.21 & 41.04 \\
\hline 27 & NDG-27 & 65.71 & 8.33 & 39.11 & 1.01 & 4.35 & 5.88 & 1.39 & 18.21 & 17.73 & 2.53 & 1.02 & 1.34 & 36.71 \\
\hline 28 & NDG-28 & 63.11 & 7.93 & 37.81 & 1.08 & 3.55 & 4.99 & 2.00 & 19.98 & 18.13 & 2.71 & 1.08 & 2.01 & 39.42 \\
\hline 29 & NDG-29 & 64.81 & 8.09 & 34.36 & 1.84 & 3.72 & 4.61 & 1.90 & 19.93 & 15.97 & 2.21 & 1.18 & 1.23 & 32.65 \\
\hline 30 & NDG-30 & 53.81 & 7.09 & 30.63 & 1.81 & 3.10 & 3.91 & 1.43 & 19.02 & 17.77 & 3.69 & 1.06 & 1.84 & 34.01 \\
\hline 31 & NDG-31 & 52.81 & 7.29 & 30.77 & 1.94 & 3.20 & 3.41 & 1.20 & 15.13 & 13.17 & 3.45 & 1.12 & 1.64 & 35.75 \\
\hline 32 & NDG-32 & 59.61 & 7.69 & 39.81 & 1.06 & 2.72 & 5.12 & 1.37 & 23.32 & 22.17 & 2.89 & 1.04 & 1.76 & 40.21 \\
\hline 33 & NDG-33 & 60.01 & 7.09 & 37.25 & 1.00 & 3.34 & 4.68 & 1.00 & 24.92 & 23.97 & 2.59 & 1.62 & 1.28 & 35.05 \\
\hline 34 & NDG-34 & 55.01 & 7.29 & 36.13 & 1.02 & 3.59 & 4.92 & 1.42 & 17.83 & 16.37 & 1.45 & 1.04 & 1.58 & 31.65 \\
\hline 35 & NDG-35 & 67.01 & 7.89 & 31.20 & 1.14 & 3.40 & 5.04 & 1.50 & 21.02 & 14.97 & 2.39 & 1.34 & 1.78 & 37.67 \\
\hline 36 & NDG-36 & 57.70 & 6.75 & 35.25 & 1.31 & 2.80 & 4.78 & 1.85 & 22.40 & 20.56 & 1.58 & 1.01 & 1.79 & 28.64 \\
\hline 37 & NDG-37 & 51.07 & 7.55 & 38.51 & 1.38 & 3.07 & 4.45 & 1.99 & 18.10 & 12.16 & 1.56 & 1.39 & 1.13 & 40.63 \\
\hline 38 & NDG-38 & 64.90 & 8.15 & 39.37 & 1.28 & 3.64 & 5.78 & 1.35 & 26.10 & 24.36 & 2.36 & 1.04 & 1.83 & 39.74 \\
\hline 39 & NDG-39 & 56.90 & 7.35 & 38.71 & 1.24 & 3.87 & 5.25 & 1.79 & 23.30 & 11.16 & 2.50 & 2.03 & 1.71 & 35.88 \\
\hline 40 & NDG-40 & 55.70 & 7.15 & 30.57 & 1.06 & 3.02 & 5.42 & 1.49 & 22.11 & 21.36 & 3.22 & 1.00 & 1.83 & 37.04 \\
\hline 41 & NDG-41 & 60.80 & 8.35 & 35.77 & 1.95 & 3.37 & 5.48 & 1.69 & 29.30 & 26.56 & 2.72 & 1.89 & 1.78 & 36.70 \\
\hline 42 & NDG-42 & 67.90 & 9.55 & 42.55 & 1.48 & 3.17 & 5.75 & 1.43 & 25.60 & 28.16 & 2.08 & 1.00 & 1.79 & 33.78 \\
\hline 43 & NDG-43 & 64.10 & 9.43 & 41.41 & 1.12 & 3.44 & 4.63 & 1.42 & 27.20 & 25.63 & 3.78 & 1.04 & 1.36 & 33.40 \\
\hline 44 & NDG-44 & 64.50 & 9.63 & 42.33 & 1.07 & 3.81 & 4.83 & 1.20 & 19.72 & 17.23 & 3.52 & 1.06 & 1.83 & 33.33 \\
\hline
\end{tabular}




\begin{tabular}{|c|c|c|c|c|c|c|c|c|c|c|c|c|c|c|}
\hline 45 & NDG-45 & 65.80 & 8.83 & 45.57 & 0.98 & 3.21 & 5.57 & 1.61 & 27.20 & 23.43 & 2.28 & 1.13 & 0.89 & 40.62 \\
\hline 46 & NDG-46 & 67.50 & 8.43 & 45.17 & 1.04 & 3.72 & 5.23 & 1.63 & 25.41 & 24.03 & 2.24 & 1.25 & 1.00 & 33.13 \\
\hline 47 & NDG-47 & 61.50 & 8.03 & 38.70 & 1.34 & 3.32 & 4.93 & 1.30 & 24.30 & 21.83 & 2.86 & 1.08 & 1.96 & 30.01 \\
\hline 48 & NDG-48 & 61.40 & 9.23 & 39.97 & 1.79 & 3.84 & 4.64 & 2.01 & 23.40 & 22.43 & 2.44 & 1.01 & 1.82 & 34.71 \\
\hline 49 & NDG-49 & 62.50 & 9.13 & 34.15 & 1.16 & 3.22 & 4.24 & 1.70 & 25.40 & 23.83 & 1.80 & 1.04 & 0.90 & 38.85 \\
\hline 50 & NDG-50 & 70.59 & 9.87 & 44.62 & 1.59 & 4.73 & 5.31 & 1.93 & 22.38 & 21.26 & 2.37 & 1.03 & 1.54 & 40.02 \\
\hline 51 & NDG-51 & 71.59 & 10.27 & 38.58 & 1.07 & 3.73 & 5.85 & 1.51 & 26.08 & 24.06 & 2.41 & 1.07 & 1.19 & 35.76 \\
\hline 52 & NDG-52 & 53.89 & 10.47 & 33.18 & 3.43 & 3.26 & 5.55 & 1.21 & 27.88 & 21.06 & 3.83 & 1.27 & 1.10 & 40.99 \\
\hline 53 & NDG-53 & 54.39 & 10.07 & 43.76 & 3.26 & 3.35 & 5.75 & 1.42 & 26.29 & 22.06 & 3.55 & 1.20 & 1.14 & 38.70 \\
\hline 54 & NDG-54 & 66.99 & 10.37 & 36.91 & 1.02 & 2.84 & 5.14 & 1.03 & 15.38 & 10.46 & 3.63 & 1.44 & 0.86 & 34.80 \\
\hline 55 & NDG-55 & 57.79 & 7.27 & 38.68 & 1.23 & 3.99 & 5.89 & 1.01 & 25.18 & 24.46 & 3.25 & 1.01 & 1.76 & 40.80 \\
\hline 56 & NDG-56 & 61.39 & 8.67 & 39.86 & 1.66 & 3.39 & 5.57 & 1.11 & 25.08 & 23.26 & 2.71 & 1.06 & 1.12 & 35.16 \\
\hline 57 & G-50 & 62.94 & 8.02 & 40.85 & 1.14 & 3.94 & 5.76 & 1.51 & 24.60 & 20.65 & 2.44 & 1.22 & 1.46 & 36.28 \\
\hline 58 & $\mathrm{G}-41$ & 55.48 & 7.45 & 35.89 & 1.20 & 3.95 & 5.28 & 1.30 & 24.28 & 22.35 & 3.09 & 1.10 & 1.69 & 35.65 \\
\hline 59 & G-282 & 56.22 & 7.64 & 37.76 & 1.87 & 3.92 & 5.84 & 1.54 & 21.86 & 14.88 & 3.56 & 1.46 & 1.84 & 35.57 \\
\hline \multirow[t]{7}{*}{60} & $\begin{array}{l}\text { Punjab } \\
\text { Garlic }\end{array}$ & 61.57 & 7.66 & 40.74 & 1.68 & 3.49 & 4.63 & 1.46 & 20.12 & 18.70 & 3.28 & 1.06 & 1.75 & 37.89 \\
\hline & Mean & 60.64 & 8.23 & 36.31 & 1.36 & 3.60 & 5.14 & 1.55 & 23.40 & 20.56 & 2.68 & 1.18 & 1.48 & 36.85 \\
\hline & Std. Dev. & 5.30 & 0.89 & 4.12 & 0.46 & 0.46 & 0.53 & 0.27 & 3.39 & 4.22 & 0.66 & 0.23 & 0.32 & 2.89 \\
\hline & Std. Error & 0.68 & 0.11 & 0.53 & 0.06 & 0.06 & 0.06 & 0.03 & 0.43 & 0.54 & 0.08 & 0.03 & 0.04 & 0.37 \\
\hline & C. V. \% & 8.74 & 10.91 & 11.36 & 34.08 & 12.87 & 10.42 & 17.50 & 14.50 & 20.55 & 24.65 & 20.20 & 22.05 & 7.85 \\
\hline & Lowest & 49.70 & 6.75 & 29.86 & 0.98 & 2.72 & 3.41 & 1.00 & 15.13 & 10.46 & 1.15 & 1.00 & 0.86 & 28.64 \\
\hline & Highest & 72.50 & 10.47 & 45.57 & 3.43 & 4.73 & 6.06 & 2.06 & 29.97 & 28.16 & 3.83 & 2.08 & 2.01 & 41.04 \\
\hline
\end{tabular}


Table.3 Estimates of range, general mean, genotypic and phenotypic coefficient of variation, heritability, genetic advance and genetic advance in percent of mean for 13 characters in garlic

\begin{tabular}{|c|c|c|c|c|c|c|c|c|}
\hline \multirow{3}{*}{ Parameters } & \multicolumn{2}{|c|}{ Range } & \multirow{2}{*}{$\begin{array}{c}\text { General } \\
\text { mean }\end{array}$} & \multirow{2}{*}{$\begin{array}{c}\text { Genotypic } \\
\text { coefficients of } \\
\text { variation }(\%)\end{array}$} & \multirow{2}{*}{$\begin{array}{l}\text { Phenotypic } \\
\text { coefficients of } \\
\text { variation }(\%)\end{array}$} & \multirow{2}{*}{$\begin{array}{l}\text { Heritability } \\
(\%)\end{array}$} & \multirow{2}{*}{$\begin{array}{l}\text { Genetic } \\
\text { advance }\end{array}$} & \multirow{2}{*}{$\begin{array}{c}\text { Genetic } \\
\text { advance } \\
\text { in percent } \\
\text { of mean }\end{array}$} \\
\hline & Min. & Max. & & & & & & \\
\hline & 1 & 2 & 3 & 4 & 5 & 6 & 7 & 8 \\
\hline Plant height $(\mathrm{cm})$ & 49.70 & 72.50 & 60.64 & 6.99 & 7.30 & 91.64 & 8.37 & 13.78 \\
\hline Number of leaves per plant & 6.75 & 10.47 & 8.23 & 8.71 & 8.88 & 96.18 & 1.45 & 17.60 \\
\hline Length of leaf $(\mathrm{cm})$ & 29.86 & 45.57 & 36.31 & 9.11 & 9.26 & 96.86 & 6.68 & 18.48 \\
\hline Width of leaf $(\mathrm{cm})$ & 0.98 & 3.43 & 1.36 & 28.74 & 28.77 & 99.78 & 0.80 & 59.14 \\
\hline Diameter of Bulb $(\mathrm{cm})$ & 2.72 & 4.73 & 3.60 & 10.63 & 10.76 & 97.70 & 0.77 & 21.66 \\
\hline Length of Bulb $(\mathrm{cm})$ & 3.41 & 6.06 & 5.14 & 8.60 & 8.76 & 96.50 & 0.89 & 17.41 \\
\hline $\begin{array}{l}\text { Neck Thickness of Bulb } \\
(\mathrm{cm})\end{array}$ & 1.00 & 2.06 & 1.55 & 14.75 & 14.80 & 99.36 & 0.47 & 30.30 \\
\hline Bulb Yield per plant (g) & 15.13 & 29.97 & 23.40 & 12.06 & 12.21 & 97.57 & 5.75 & 24.55 \\
\hline Number of cloves per Bulb & 10.46 & 28.16 & 20.56 & 17.07 & 17.17 & 98.84 & 7.22 & 34.96 \\
\hline Length of Clove $(\mathrm{cm})$ & 1.15 & 3.83 & 2.68 & 21.08 & 21.19 & 98.98 & 1.14 & 43.21 \\
\hline Weight of Clove (g) & 1.00 & 2.08 & 1.18 & 17.11 & 17.15 & 99.46 & 0.41 & 35.15 \\
\hline Diameter of Clove $(\mathrm{cm})$ & 0.86 & 2.01 & 1.48 & 18.80 & 18.89 & 99.11 & 0.56 & 38.56 \\
\hline Total Soluble Solids (\%) & 28.64 & 41.04 & 36.85 & 6.30 & 6.62 & 90.41 & 4.55 & 12.34 \\
\hline
\end{tabular}


The estimates of genotypic and phenotypic coefficient of variation were recorded as 12.06 and 12.21 per cent, respectively and the estimate of heritability in broad sense was high $(97.57 \%)$ with moderate genetic advance in per cent of mean i.e. 24.55 for bulb yield per plant. Which revealed that this trait are governed by additive gene action and phenotypic selection would be effective for the improvement of bulb yield per plant. The estimates of genotypic and phenotypic coefficient of variation were recorded as 17.07 and 17.17 per cent, respectively and the estimate of heritability in broad sense was high (98.84\%) with higher genetic advance in per cent of mean i.e. 34.96 for number of cloves per bulb. The estimates of genotypic and phenotypic coefficient of variation were recorded as 21.08 and 21.19 per cent, respectively and the estimate of heritability in broad sense was high (98.98\%) with higher genetic advance in per cent of mean i.e. 43.21 for length of clove. Which revealed that this trait are governed by additive gene action and phenotypic selection would be effective for the improvement of length of clove. The estimates of genotypic and phenotypic coefficient of variation were recorded as 17.11 and 17.15 per cent, respectively and the estimate of heritability in broad sense was high $(99.46 \%)$ with higher genetic advance in per cent of mean i.e. 35.15 for weight of clove. Which revealed that this trait are governed by additive gene action and phenotypic selection would be effective for the improvement of weight of clove. The estimates of genotypic and phenotypic coefficient of variation were recorded as 18.80 and 18.89 per cent, respectively and the estimate of heritability in broad sense was high $(99.11 \%)$ with higher genetic advance in per cent of mean i.e. 38.56 for diameter of clove. The estimates of genotypic and phenotypic coefficient of variation were recorded as 6.30 and 6.62 per cent, respectively and the estimate of heritability in broad sense was high $(90.41 \%)$ with low genetic advance in per cent of mean i.e. 12.34 for total soluble solids. Which revealed that this trait are governed by additive gene action and phenotypic selection would be effective for the improvement of total soluble solids. In the present investigation, high heritability coupled with high genetic advance as per cent of mean was observed for width of leaf, neck thickness of bulb, number of cloves per bulb, length of clove, weight of clove and diameter of clove. This indicates that these traits were less influenced by environment. Similar results were reported by Singh and Chand (2004), Kohali (2001), and Khar et al., (2005). Whereas, high heritability coupled with moderate genetic advance observed for diameter of bulb and bulb yield per plant and moderate heritability coupled with moderate genetic advance is observed for number of leaves per plant and plant height. While total soluble solids (TSS) showed lowest heritability. Similar results were reported by Agrawal and Tiwari (2004).

Considering the overall result it is apparent that certain information obtained here will help in future for improving existing garlic genotypes.

\section{References}

Agrawal, A. and Tiwari, R.S. 2004. Genetic variability in garlic. Ind. J. Agric. Sci. 74 (3): 164-165.

Anonymous 2015. Database area and production of garlic 2015. National Horticultural Board, Ministry of Agriculture and farmers Welfare, Gurgaon (Haryana).

Augusti, K.T. 1977. Ind. J. Exp. Biol. 15: 489-90.

Burton, G.W. and de Vane, E.W. 1953. Estimating heritability in tall fescue (Festuca arundincea) from replicated clonal material. Agron. J. 45:178-181. 
Federer, W.T. 1956. Augmented designs, "Hawain Planters". Record, 55:191-208.

Johnson, H.W., Robinson, H.F. and Comstock R.I. 1955. Estimates of genetic and environmental variability in soybean. Agron. J ,47: 314-318.

Khar, A., Mahajan, V., Devi, A.A. and Lawande, K.E. 2005. Genetic studies in elite lines of garlic (Allium sativum L.). J. Maharastra Agric. Univ, 30 (3): 277-
280.

Kohli, U.K., Prabal 2000. Variability and correlation studies on some important traits in garlic (Allium sativum L.) clones. Haryana J. Horti. Sci. 29 (3/4): 209-211.

Singh, Y. and Chand, R. 2004. Genetic variability in garlic. Haryana $J$. of Horti. Sci. 33 (1/2): 146-147.

\section{How to cite this article:}

Gaurav Singh, C.N. Ram, Angad Singh, Shiv Prakash Shrivastav, Praveen Kumar Maurya, Prateek Kumar and Sriom. 2018. Genetic Variability, Heritability and Genetic Advance for Yield and its Contributing Traits in Garlic (Allium sativum L.). Int.J.Curr.Microbiol.App.Sci. 7(02): 1362-1372. doi: https://doi.org/10.20546/ijcmas.2018.702.165 